\title{
SIMULASI KUAT PENERANGAN GEDUNG BERTINGKAT MENGGUNAKAN SOFTWARE DIALUX EVO 6.2. DI GEDUNG L1 TEKNIK ELEKTRO UNIVERSITAS NEGERI JAKARTA \\ ${ }^{1}$ Azhari Jum'atullah, ${ }^{2}$ Irzan Zakir, ${ }^{3}$ Massus Subekti \\ ${ }^{1,2,3}$ PendidikanTeknik Elektro, Fakultas Teknik, Universitas Negeri Jakarta
}

\begin{abstract}
The purpose of this research is to get the strong value of lighting at L1 building of Universitas Negeri Jakarta and compare the measurement result using luxmeter with software of Dialux Evo 6.2.

This research uses engineering methods by utilizing three ways of measurement, manual calculation and simulation of Dialux Evo 6.2. Measurement method using Luxmeter as measuring instrument to get the measured value of the measured light in the learning room based on the standard procedure of calculation according to SNI and the simulation using the program of Dialux Evo 6.2 to predict the strong value of the illumination that should be in the building.

The results of this study indicate that the average value of the average light is still not much according to the standard. Then by manual calculation and simulation, the strong value of illumination that should be in the building is also below 350 lux for study room, under 500 lux for laboratory, and under 750 lux for technical drawing room. Then to improve the design of the high rise building, to achieve a strong value of lighting above 350 lux, 500 lux and 750 lux can be obtained by changing the wall color characters that increased to reach 39.6 percent, a 52-84 percent increase after changing the point of light, as well as an increase of 54-85 percent after changing the color of the walls and the point of light.
\end{abstract}

Keywords: Multi-story Building, Powerful Artificial Lighting, Measurement, Calculation, Simux Dialux Evo 6.2, Design Improvement.

\begin{abstract}
Abstrak
Tujuan dari penelitian ini adalah untuk mendapatkan nilai kuat penerangan pada gedung L1 Universitas Negeri Jakarta dan membandingkan hasil pengukuran menggunakan luxmeter dengan software Dialux Evo 6.2.

Penelitian ini menggunakan metode rekayasa teknik dengan memanfaatkan tiga cara yaitu pengukuran, perhitungan manual dan simulasi Dialux Evo 6.2. Cara pengukuran menggunakan Luxmeter sebagai alat ukur untuk mendapatkan nilai kuat penerangan yang terukur pada ruang belajar berdasarkan standar tata cara perhitungan menurut SNI dan cara simulasi menggunakan program Dialux Evo 6.2 untuk memprediksi nilai kuat penerangan yang seharusnya terdapat pada gedung bertingkat.

Hasil penelitian ini menunjukan bahwa nilai kuat penerangan rata-rata yang masih banyak yang belum sesuai standar. Kemudian dengan cara perhitungan manual dan simulasi, nilai kuat penerangan yang seharusnya terdapat pada gedung bertingkat tersebut juga masih dibawah 350 lux untuk ruang belajar, dibawah 500 lux untuk laboratorium, dan dibawah 750 lux untuk ruang gambar teknik. Kemudian pada perbaikan desain gedung bertingkat tersebut, untuk mencapai nilai kuat penerangan di atas 350 lux, 500 lux dan 750 lux dapat diperoleh dengan merubah karakter warna dinding yang mengalami kenaikan mencapai 3-9,6 persen, kenaikan 52-84 persen setalah merubah titik lampu, serta kenaikan 54-85 persen setelah merubah warna dinding dan titik lampu.
\end{abstract}

Kata Kunci: Gedung Bertingkat, Kuat penerangan Buatan, Pengukuran, Perhitungan, Simulasi Dialux Evo 6.2, Perbaikan Desain.

\section{PENDAHULUAN}

Semakin banyaknya kebutuhan pencahayaan untuk aktifitas sehari-hari, pencahayaan menjadi salah satu faktor untuk mendapatkan keadaan lingkungan yang aman dan nyaman yang berkaitan erat dengan produktivitas manusia. Pencahayaan pada suatu ruangan sangat dibutuhkan dalam kehidupan sehari-hari terutama pada rumah bertingkat. merupakan salah satu faktor penting dalam perancangan ruang untuk menunjang kenyamanan pengguna.
Ruang dengan sistem pencahayaan yang baik dapat mendukung aktivitas yang dilakukan di dalamnya. Sistem pencahayaan yang baik harus dapat memenuhi tiga kriteria utama, yaitu kualitas, kuantitas, dan aturan pencahayaan. Kurangnya dukungan pencahayaan dalam suatu ruang mengakibatkan aktivitas dalam ruangan tersebut menjadi terganggu misalnya ketika pencahayaan terlalu berlebihan akan berakibat mengganggu penglihatan.

Dengan demikian intensitas cahaya perlu diatur untuk menghasilkan kesesuaian 
kebutuhan penglihatan di dalam ruang berdasarkan jenis aktivitas-aktivitasnya.

Seiring berkembangnya zaman, perencanaan instalasi penerangan menjadi semakin canggih dan mudah. Berawal dari perencanaan yang hanya dibuat di atas kertas, sampai terciptanya sebuah software untuk membuat sebuah perencanaan instalasi listrik, salah satunya yaitu AutoCAD yang muncul di tahun 1982 dan masih digunakan sampai sekarang. Hingga akhirnya tercipta sebuah software yang lebih canggih dan teliti dalam melakukan perencanaan instalasi yang disebut Dialux. Dialux yaitu software yang berasal dari Jerman. Kelebihan dari software ini adalah tidak hanya mengandalkan dari sisi engineer nya saja, namun juga dari sisi visualisasi. Dengan menggunakan Dialux, kita dapat mensimulasi ruang dengan menggunakan lampu yang benar - benar tersedia pada industri lampu dunia.

Oleh karena itu hasil kalkulasi dan rendering akan menyerupai dengan keadaan yang sebenarnya. Pada software ini, kita juga dapat memilih spesifikasi lampu yang kita inginkan, baik dari segi distribusi cahayanya, klasifikasi lampu atau melihat diagram polar dari lampu tersebut, sehingga kita dapat memutuskan, jenis lampu seperti apa yang kita butuhkan pada project yang ingin digarap.

Atas dasar inilah yang melandasi peneliti untuk membuat simulasi penerangan gedung bertingkat menggunakan software Dialux evo 6.2 .

\section{METODE PENELITIAN}

Berikut metode pengumpulan data, penelitian dengan judul : "Optimasi Kuat Penerangan Pada Gedung Bertingkat Menggunakan software Dialux evo 6.2."

1. Pada tahap persiapan, pertama peneliti mengurus perizinan dari setiap Kaprodi jurusan teknik elektro Universitas Negeri Jakarta untuk mengambil data pengukuran pada gedung bertingkat.

2. Pada tahap pelaksanaan, pertama kali peneliti mempersiapkan lingkungan tempat akan dilakukannya pengukuran sesuai dengan arahan pihak pengelola gedung L1 Universitas Negeri Jakarta.
3. Pelaksanaan pengukuran menggunakan luxmeter pada setiap ruangan yang akan di analisis dan disimulasikan pada software Dialux evo 6.2.

4. Peneliti melakukan analisa data hasil pengukuran dan menyimpulkan hasil penelitian yang telah dilakukan.

5. Dari simulasi akan didapatkan suatu hasil yang nantinya akan dianalisa dan dibandingkan dengan data objek yang didapatkan melalui pengukuran manual.

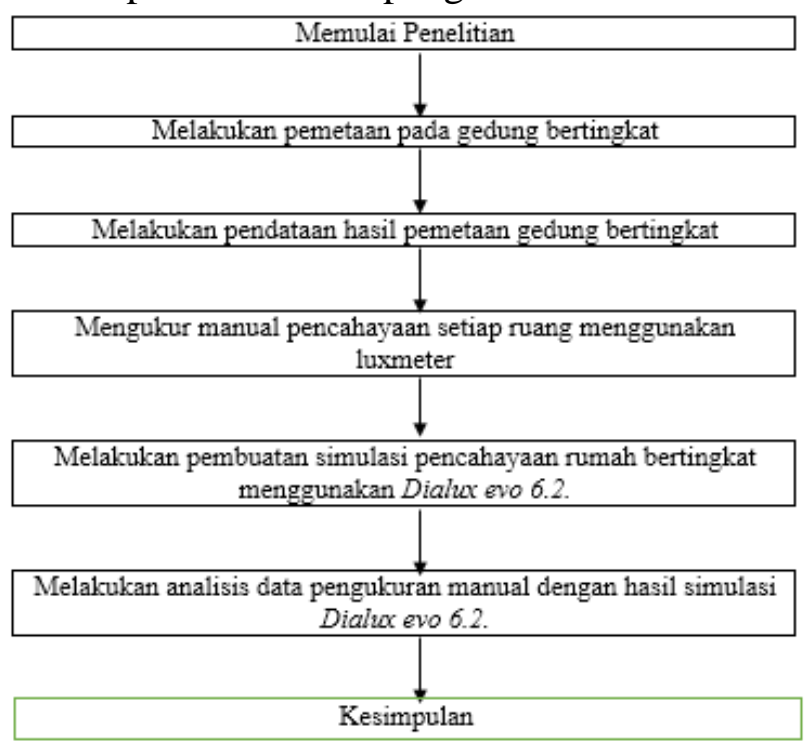

Gambar 1. Skema Penelitian

\section{HASIL DAN PEMBAHASAN}

Setelah melakukan analisis data pengukuran menggunakan luxmeter dan cara simulasi dengan menggunakan Dialux Evo 6.2 didapatkan beberapa hasil analisis dengan nilai kuat penerangan atau iluminasi yang berbeda pada setiap ruangan dengan satuan lux.

Tabel 1. Hasil Pengukuran Menggunakan Luxmeter dan Dialux Evo 6.2

\begin{tabular}{lcr}
\hline \multicolumn{1}{c}{ Ruang } & $\begin{array}{c}\text { Luxmeter } \\
\text { HIOKI 3241 }\end{array}$ & $\begin{array}{c}\text { Dialux } \\
\text { Evo 6.2 }\end{array}$ \\
\hline Ruang TIL & 98,3 & 234 \\
Ruang Pengukuran Listrik & 79,3 & 134 \\
Ruang Teknik Pendingin & 86,5 & 254 \\
Ruang Pengendali Motor & 91,3 & 203 \\
Ruang PLC & 71,8 & 263 \\
Ruang Gambar Teknik & 105 & 129 \\
Ruang Bengkel & 45 & 136 \\
Ruang Sidang & 58,5 & 68,4 \\
Ruang Dosen & 75 & 195 \\
\hline
\end{tabular}

Berdasarkan tabel 1 pengukuran pada ruang TIL menggunakan luxmeter HIOKI 3241 
sebesar 98,3 lux, dan simulasi menggunakan Dialux Evo 6.2 sebesar 234 lux. Pada ruang pengukuran listrik menggunakan luxmeter HIOKI 3241 sebesar 79,3 lux, dan simulasi menggunakan Dialux Evo 6.2 sebesar 134 lux. pada ruang teknik pendingin menggunakan luxmeter HIOKI 3241 sebesar 86,5 lux, dan simulasi menggunakan Dialux Evo 6.2 sebesar 254 lux. Pada ruang pengendali motor menggunakan luxmeter HIOKI 3241 sebesar 91,3 lux, dan simulasi menggunakan Dialux Evo 6.2 sebesar 203 lux. Pada ruang PLC menggunakan luxmeter HIOKI 3241 sebesar 71,8 lux, dan simulasi menggunakan Dialux Evo 6.2 sebesar 263 lux. Pada ruang gambar teknik menggunakan luxmeter HIOKI 3241 sebesar 105 lux, dan simulasi menggunakan Dialux Evo 6.2 sebesar 129 lux. Pada ruang bengkel menggunakan HIOKI 3241 sebesar 45 lux, dan simulasi menggunakan Dialux Evo 6.2 sebesar 136 lux. Pada ruang sidang menggunakan luxmeter HIOKI 3241 sebesar 58,5 lux, dan simulasi menggunakan Dialux Evo 6.2 sebesar 68,4 lux. Pada ruang dosen menggunakan luxmeter TENMARS TM-204 sebesar 82 lux sedangkan luxmeter HIOKI 3241 sebesar 75 lux, dan simulasi menggunakan Dialux Evo 6.2 sebesar 195 lux.

Tabel 2. Hasil Kuat Penerangan dengan 3 Skenario

\begin{tabular}{cccc} 
& \multicolumn{3}{c}{ Perbaikan } \\
\cline { 2 - 4 } Ruang & $\begin{array}{c}\text { E } \\
\text { (Perbaikan } \\
\text { Merubah } \\
\text { Warna } \\
\text { Dinding) }\end{array}$ & $\begin{array}{c}\text { E } \\
\text { (Perbaikan } \\
\text { Merubah } \\
\text { Titik } \\
\text { Lampu) }\end{array}$ & $\begin{array}{c}\text { E (Perbaikan } \\
\text { Merubah } \\
\text { Warna } \\
\text { Dinding Dan } \\
\text { Titik Lampu) }\end{array}$ \\
\hline $\begin{array}{c}\text { Lab Pengukuran } \\
\text { Listrik }\end{array}$ & 245 & 510 & 530 \\
Lab Teknik Pendingin & 266 & 538 & 555 \\
$\begin{array}{c}\text { Lab Pengendali Motor } \\
\text { Lab Teknik Instalasi } \\
\text { Listrik }\end{array}$ & 215 & 626 & 649 \\
Ruang Sidang & 140 & 540 & 570 \\
Ruang PLC & 75,7 & 431 & 456 \\
Ruang Gambar Teknik & 140 & 767 & 786 \\
Ruang Bengkel & 142 & 641 & 667 \\
Ruang Dosen & 215 & 406 & 437 \\
\hline
\end{tabular}

\section{KESIMPULAN DAN SARAN \\ Kesimpulan}

1. Nilai rata-rata kuat penerangan yang terukur menggunakan luxmeter HIOKI 3241 dan simulasi menggunakan Dialux Evo.6.2 masih belum memenuhi standar penerangan berdasarkan SNI.

2. Terdapat perbedaan nilai kuat penerangan antara hasil perhitungan dengan cara manual dan dengan cara simulasi Dialux Evo 6.2. Pada perbaikan desain lantai 1 gedung L1 Teknik Elektro Universitas Negeri Jakarta, untuk mencapai nilai kuat penerangan di atas 350 lux pada ruang belajar, ruang kerja 500 lux untuk laboratorium, dan 750 untuk ruang gambar teknik dapat diperoleh dengan merubah karakter warna dinding 80\% menjadi $90 \%$ dan menambah titik penerangan dan mengganti sumber penerangan dengan lampu yang jumlah lumennya lebih tinggi.

3. Desain perbaikan menggunakan software Dialux evo 6.2 pada lantai 1 dengan hanya merubah warna dinding mengalami kenaikan 3-9,6 persen pada setiap ruangan. Dengan merubah titik lampu mengalami kenaikan 5284 persen pada setiap ruangan. Serta dengan merubah warna dinding dan titik lampu mengalami kenaikan 54-85 persen.

\section{Saran}

1. Untuk meningkatkan nilai kuat penerangan pada gedung bertingkat perlu diperhatikan penggunaan karakter warna yang cerah dan dapat memantulkan cahaya serta kebersihan dinding dan langit-langit yang bisa mempengaruhi nilai kuat penerangan dalam ruang belajar serta spesifikasi lampu yang harus disesuaikan dengan pemakaiannya.

2. Simulasi program Dialux Evo 6.2 bisa menjadi salah satu peluang yang bagus dalam memprediksi nilai kuat penerangan pada suatu ruang atau bangunan dengan proses light calculation yang mudah difahami dan dioperasikan serta hasil keluaran data yang lengkap.

\section{DAFTAR PUSTAKA}

Arikunto, Suharsimi. (1996). Prosedur Penelitian Suatu Pendekatan Praktek.Jakarta: Penerbit Rineka Cipta.

Benya, James \& Karlen, Mark (2007). Dasar-Dasar Desain Pencahayaan. Jakarta: Penerbit Erlangga. 
Budiaji. (2015, 18 Oktober). Faktor Bahaya Kurangnya Intensitas Pencahayaan di Tempat Kerja. www.belajark3.com. Diakses 24 Mei 2016.

Depdikbud. (1996). Kamus Besar Bahasa Indonesia (KBBI). Jakarta: Balai Pustaka.

DIALux Evo. 2015. Manual Operation For DIALux Evo. Germany : DIALux GMBH.

Listia,.Gita..(2008,.21.Desember).

DIALux..https://gitalistia.wordpress.com/2008/12/26/ dialux/. Diakses 13 Mei 2017.

Mujib, Farid Khusnul. (2012). Desain Pencahayaan Lapangan Bulu Tangkis Indoor ITS (skripsi). Surabaya: Fakultas Teknik, Institut Teknik Surabaya.

Sugiyono. (2009). Metode Penelitian Kuantitatif Kualitatif $R \& D$. Bandung:Penerbit Alfabeta.

[Anonim]. 2009. Sistem dan standar pencahayaan ruang. https://putraprabu.wordpress.com. Diakses 24 Agustus 2017 